\title{
COMPETITIVENESS OF VIETNAM CONSTRUCTION ENTERPRISES IN THE INTEGRATION PROCESS: BASIS FOR INTERVENTION SCHEME
}

\author{
Dr. Nguyen Thien Hung \\ Sai Gon Technology University (STU), Hochiminh City, Vietnam \\ Dr. Nguyen Van It \\ Hochiminh City University of Food Industry (HUFI), Vietnam
}

http://doi.org/10.35409/IJBMER.2021.3227

\begin{abstract}
Competitiveness is the inherent characteristic of market economy and in the integration process of Vietnam, competition is becoming fierce. Competitiveness is considered an important condition for existence and development of economy as well as the business. In Vietnam, at present there are many businesses are operating in the construction field with four models are private company, JSC (State), Joint venture and foreign company. So, to win the competition requires the business managers must capture the market and continuously improve capacity of business in the market. Managers must continually find ways to strengthen and perfect the enterprise gaining greater market shares. This research study proposed some solutions to improve the competitiveness of Vietnam construction enterprises in the integration process.
\end{abstract}

Keyword: Competitiveness, Vietnam construction enterprises, In the integration process.

\section{INTRODUCTION}

Globalization and international integration has opened a new era for the development of human society, it is stage that all activities of economic, political, cultural, social, not framed within any a country, it has spread to penetrate into each other, influence each other deeply, have the ability to make each country to develop richer and more powerful.

In the process of integration into world economy, Vietnam is actively implementing the commitments of bilateral and multilateral, a factor ensures the survival and development of businesses as well as the development of economy that is competitive because the competitiveness is a characteristic of market economy and in terms of integration, the competition is becoming fierce.

Competition is an inevitable rule, motivate enterprises as well as market economy to develop. Nowadays in the market economy, competition among businesses in general and the construction enterprises in particular happen increasingly stress.

Currently in Vietnam, there are many enterprises which are operating in construction field with four main types such as JSC (State), private companies, Joint venture companies and foreign companies. Much of Vietnam construction enterprises still not consider the competitive strategy is very important. Some enterprises were initially reaching out to regional markets such 


\section{International Journal of Business Management and Economic Review}

Vol. 4, No. 01; 2021

ISSN: 2581-4664

as Laos, Cambodia, Myanmar and China but it is only the modest steps of enterprises which are still very limited. Therefore, to win the competition requires the business managers must capture the market and continuously improve capacity of business in the market.

In front of the challenges, competitiveness is considered an important condition for the existence and development of economy as well as the construction businesses. To improve competitiveness on the market, managers must continually find ways to strengthen and perfect the enterprise gaining greater market shares.

\section{THEORETICAL FRAMEWORK}

A theoretical framework guides research, determining what variables to measure, and what statistical relationships to look for. William, Trochim, and P. Donnelly James(2006) in The Research Methods Knowledge Base, states that there are two realms involved in researchtheory and observation. Theory is what goes on inside the heads of scientists while observation is what goes on in the real world or measures and observations. In conducting research, one works between these two realms. Theory guides every aspect of research, from formulation of the research question through operationalization and discussion.

This study based on theoretical of Local Competitive Index of Vietnam Construction Association; Theory about Advantage Competition of M.Porter (1980);

Global Competitiveness of Jacques Hamilton, L., \& Webster, P. (2018).

To explicitly show and explain how the researches will be used to conduct the study scientifically and systematically the Input - Process - Output was utilized: 
International Journal of Business Management and Economic Review

Vol. 4, No. 01; 2021

ISSN: 2581-4664

\section{CONCEPTUAL FRAMEWORK}

INPUT PROCESS OUTPUT

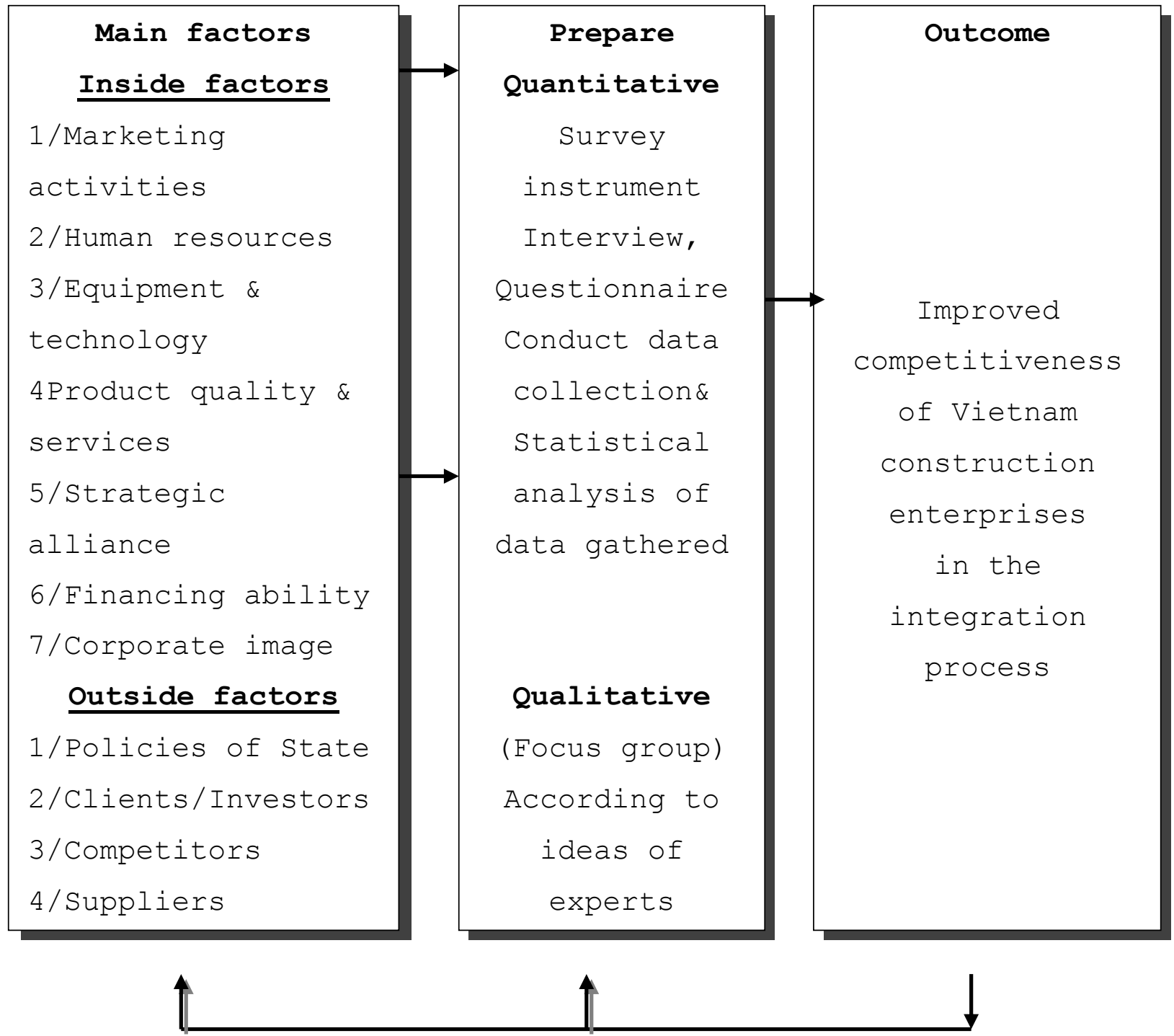




\section{International Journal of Business Management and Economic Review}

Vol. 4, No. 01; 2021

ISSN: 2581-4664

\section{LITERATURE REVIEW}

To have a clear understanding of this study, the following terms were operationally and lexically defined:

Marketing activities are the entire system of business activities from designing, valuating, promoting and distributing products aim at satisfying the needs of target market to achieve these goals.

For businesses, marketing is the most important tools to help them competitive strategy planning. With their marketing policies system not only help the enterprises choose investments, capitalizing on full advantage of business opportunities but also help them build a competitive strategy and use of weapons effective competition, to enhance credibility, convince customers and increase competitiveness in the market.

Production of construction is often conducted under specific orders (economic contracts in construction) depends on the characteristics of the locality where construction and requirements of users. In many other industries, they can manufacture mass product not know specifically where and users, and then offer goods, but building works must be based on the construction contract basis.

Marketing in construction has a difference, customers of construction business (investors) usually has the following characteristics:

$\checkmark \quad$ The number of customers less;

$\checkmark \quad$ Customers are largely determined before production;

$\checkmark \quad$ The purchase of construction products is often lengthy and complicated;

$\checkmark \quad$ Complex process over the periods, since the swap of information preparation of tender documents to win the bid and construction process;

To note that the product to adapt to market demand and make a positive impact to the market conditions are acts of corporate marketing, also valuable for the construction business. Products adapted to market needs to understand as adhere with the technical design documents, art, ensuring on time the construction schedule, ensure quality construction as required in the construction contract signed. Construction enterprises can and should make a positive impact to the market conditions by business advertising, create good public relations with other potential investors.

Human resources: human is a resource of great importance because it creates other sources. The manpower of enterprise is the most precious capital. The level of human resources expressed management level of leadership, the skills of employees. High degree of human resources to create products with high quality standards of engineering, art, making it increasingly important for construction businesses. The capacity of the leadership shows in the "internal" and "external" of enterprise. On internal activity, this capacity is in place to develop the knack of individual and collective potential of the business. Regarding external relations, leadership capacity knows visionary, has a range of observations and analysis, capture the needs of customer, market, predict exactly opportunities, risk from environmental, can handle well the relationship with relevant external object (investors, State agencies, local, etc.) to take advantage of opportunities and avoid risks to the enterprise.

In the organization of construction enterprises, Human resource includes Board, managers, 


\section{International Journal of Business Management and Economic Review}

Vol. 4, No. 01; 2021

ISSN: 2581-4664

staffs, engineers, workers and other attendants.

Equipment \& technology: reflected by the total value of assets as machineries, equipment $\&$ software are current of enterprise about quantity, types as well as its synchronization. The competency about the equipment and technology are introduced by enterprises in the profile documents of contractors in participating the bidding, it demonstrated to investors is that the ability to ensure the implementation of construction. Technological capability is not only reflect in equipment technology but also in qualifications, skills and techniques of workers in enterprises, especially the ability of managers to organize the construction of construction.

An enterprise has high-tech level but no labor force and managers use effectively technology that means not have competitive skill. Appropriate technology, modern is a condition necessary to create products or works of high quality, low cost with advanced features than competitors.

Product Quality \& services is the important tool that businesses use to win the competition. Businesses need to set a target quality of their products on the first top. Products of construction are not like other commodities, production and bring them to consumption market. It needs pre-ordered specific (needs to be determined prior to production). Therefore, enterprises should create their position in market, to do that is the inevitable product of the enterprise to create the trust from customers. Product quality means durability of the project, reliability of works and the safety of the works. Services support maintenance after finishing the projects.

Strategic alliance is a combination of two or more economic entities to create a new legal entity and has more synergy experience capacity, financial capacity. Partnership links is also a way to improve the competitiveness of enterprises. This is an important solution and suitable to meet the requirements of large scales projects and high complexity. Also through partnerships that link businesses to expand relationships with partners, looking to collect more information and training for staffs have the skills to do the coordination. It is also important that the linking of partners can supplement the knowledge learned and experiences from partners to help business can be stable in marketplace.

Financing ability: Financial capacity is one of the important factors to consider potential strength or weakness of the business. Financial capacity of enterprises is not only reflect in the scale of business capital. There are large-scale enterprises but capital is not strong, because it is the structure of assets, capital does not match the scale and characteristics production and business of enterprises. Enterprises do not know how to exploit and effectively use their financial resources, to avoid the risk not arrears in payment. Conversely, there are small scale businesses but are still considered strong because the business has maintained a good financial situation, know how to mobilize adequate financial resources for production and business, products have competitiveness serve good for market.

Corporate image:This is a very influential factor to the competitiveness of enterprises. Prestige of the business position not only is to form for a moment that is a long process of striving, persistent pursuit of his right strategy (brand name of enterprise) prestige \& position firstly is constructed by quality. The quality of whole enterprise management system, quality of leadership, the quality of each person in the business, quality are formed through the process of education and training, reputation is built with quality products that businesses make. Product quality must be regular and stable, constantly improving and raising the difference. So there are new products to meet customer requirements, products have quality. Secondly, prestige; position 


\section{International Journal of Business Management and Economic Review}

Vol. 4, No. 01; 2021

ISSN: 2581-4664

is built on contribution of business to sustainable development of economy and society. Thirdly, letting customers know about enterprise, knowing product. Enterprises need to attention business marketing and advertising activities. If the product is good without advertising, consumers will not know to order. Therefore, businesses need advertising honest if it does not become counterproductive.

Competitiveness (Feurer, R. and Chaharbaghi, 1994): is relative and not absolute. It depends on shareholder and customer values, financial strength which determines the ability to act and react within the competitive environment and the potential of people and technology in implementing the necessary strategic changes. Competitiveness can only be sustained if an appropriate balance is maintained between these factors which can be of conflicting nature.

\section{METHODOLOGY USED}

The descriptive survey method of research employing a questionnaire was used in the conduct of this study. Four hundred and fifty (450) composed of the managers and experts in construction were the respondents of the study.

The data obtained were consolidated, organized and tabulated in distribution tables. They were analyzed and interpreted using the following statistical tools: percentage, weighted mean, Chi-square (X2) of independent samples and significance.

\section{RESULT}

\begin{tabular}{|lccc|}
\hline \multicolumn{1}{|c}{ Factors } & $\begin{array}{c}\text { Weighted } \\
\text { Mean }\end{array}$ & $\begin{array}{c}\text { Verbal } \\
\text { Interpretation }\end{array}$ & Rank \\
\hline 1. Marketing activities & 3.65 & Highly Agree & 6 \\
2. Human resources & 3.77 & Highly Agree & 3.5 \\
3. Equipment \& technology & 3.62 & Highly Agree & 7 \\
4. Product quality \& services & 3.77 & Highly Agree & 3.5 \\
5. Strategic alliances & 3.73 & Highly Agree & 5 \\
6. Financing ability & 3.98 & Highly Agree & 1 \\
7. Corporate image & 3.83 & Highly Agree & 2 \\
Composite Weighted Mean & 3.76 & Highly Agree & \\
\hline
\end{tabular}

Factors that reflect the Competitiveness of Construction Enterprises in Inside and Outside

Legend:

\begin{tabular}{|c|c|c|}
\hline Scale & Numerical Value & Descriptive Value \\
\hline 5 & $4.20-5.00$ & Very Highly Agree (VHA) \\
\hline 4 & $3.40-4.19$ & Highly Agree (HA) \\
\hline 3 & $2.60-3.39$ & Agree (A) \\
\hline 2 & $1.80-2.59$ & Fairly Agree (FA) \\
\hline 1 & $1.00-1.79$ & Not Agree (NA) \\
\hline
\end{tabular}

As manifested in the data, all items were rated by the respondents as highly agree: 3.98 for financing ability rank 1; 3.83 for corporate image rank $2 ; 3.77$ for human resources rank 3.5; 


\section{International Journal of Business Management and Economic Review}

Vol. 4, No. 01; 2021

ISSN: 2581-4664

3.77 for product quality and services rank $3.5 ; 3.73$ for strategic alliances rank $5 ; 3.65$ for marketing activities rank 6; and 3.62 for equipment and technology.

The computed composite mean value of 3.76 reveals that the respondents are highly agree on the factors that reflect the competitiveness of construction enterprises in inside and outside.

\section{Based on the result of the study, what intervention scheme may be proposed?}

Through qualitative research method (focus group) and quantitative research method, author submits official research model that shows the factors affect to competitiveness of Vietnam construction enterprises in the integration process as followings

$\underline{\text { Inside factorsOutside factors }}$

[

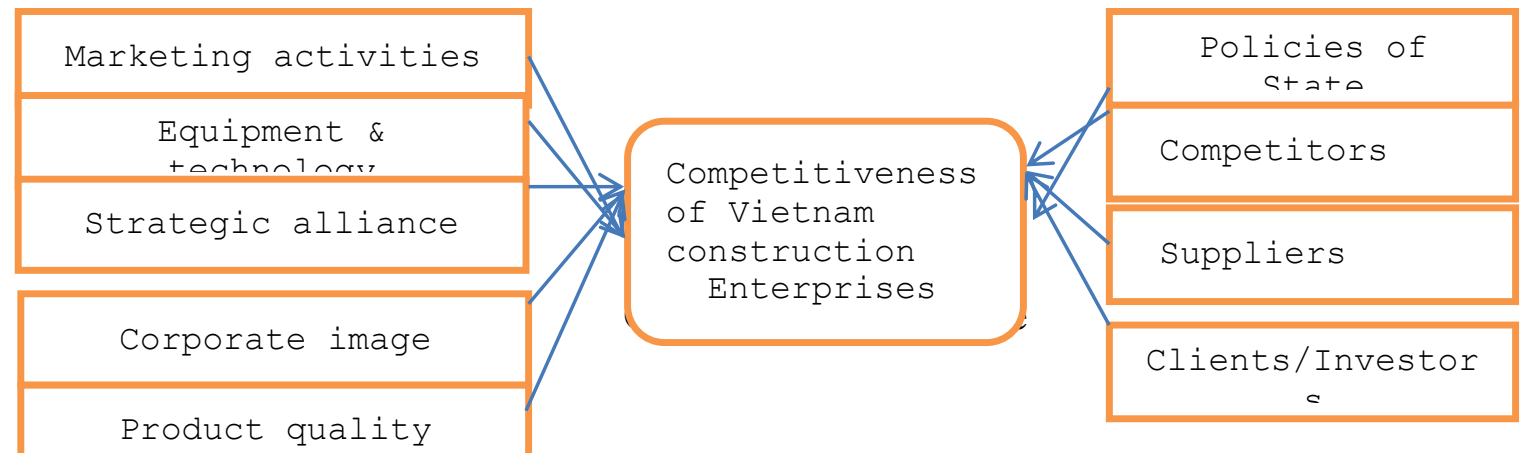

\section{FINDINGS}

Taking into consideration the data gathered which were analyzed, validated and interpreted, the following findings are presented:

\section{Profile of the Respondents as to:}

a. Age. 23.11 percent of the respondents have an age ranges from 55 years and above, followed by 25 years old and below of 20.89 percent, 45-54 years old 19.11 percent, 35-44 years old, 18.22 percent in that order. It appears that most of the respondent age ranges from 44 and up bracket.

b. Gender. 51.33 percent of the respondents were males, they exceeded the percentage of the female by 2.76 percent.

c. Years of experience. 22.33 percent ranges 5 years and below, followed 20.89 percent of the respondent have experience ranging from 15-19 years, 10-14 years of experience 20\%; 5-9 yearsexperience 19.11 percent and 20 years and above 18.67 percent. It appears that most of the respondents have experience ranging 10 years and below.

d. Educational Attainment. 105 or 23.33 percent were in college level followed by masters degree holder of 95 or 21.11 percent, doctorate degree holder 93 or 20.67 percent, bachelor degree 


\section{International Journal of Business Management and Economic Review}

Vol. 4, No. 01; 2021

ISSN: 2581-4664

holder 80 or 17.78 percent and other 77 or 17.11 percent. It appears that majority of the respondents are well educated ranging from bachelors degree to doctorate degree.

\section{Level of Competitiveness with Regards to the Eight Factors considered}

e. Marketing activities of the nine criteria considered were assess to be highly agree with a composite weighted mean of 3.43 rated as highly agree, indicating that there is competition that exist among enterprises as to marketing activities.

f. Human Resources. Of the seven criteria considered in the assessment three were rated highly agree while the rest were rated agree and a composite weighted mean of 3.42 rated as highly agree an indication that there exist competition of enterprises to human resources.

g. Equipment and Technology. Of the six (6) criteria of measuring level of competition with regards to equipment and technology, the composite weighted mean is 3.44 rated as highly agree indicating that equipment and technology is one factor that competition existed.

h. Product Quality and Services. Of the six (6) criteria considered in measuring if there exist competition when product quality and services is considered, it appears that all were rated highly agree and the composite weighted mean of 3.43 rated as highly agree hence indicating that product quality and services is one factor that competition occurs.

i. Strategic Alliances. These factors of measuring competitiveness of Vietnam Construction Enterprises shows that out of three (3) criteria considered all were rated highly agree indicating that strategic alliance is one factor in measuring the competitiveness of construction enterprises.

j. Financial Ability. In measuring whether or not financial ability could be considered as one factor in determining competitiveness of a construction enterprises of the seven (7) criteria it manifested that six (6) were highly agree and one (1) agree but the overall weighted mean of 3.42 rated as highly agree indicative that financial ability is one factor considered in the competitiveness of a construction enterprises in Vietnam.

k. Composite Image. Of the seven (7) criteria considered in determining whether composite image play a role in the competitiveness of the construction enterprises it appears that the overall weighted mean is 3.44 rated highly agree an indication that composite image plays a very important role in the competitiveness of a construction enterprises in Vietnam.

1. Competitiveness. This factor refers to the ability of the enterprise to win bidding, providing superior quality and limiting cost which was measured by three (3) criteria and the composite weighted mean of 3.42 rated as highly agree indicating that it is highly considered as basis in determining the competitiveness of the construction enterprises in Vietnam.

Considering the composite weighted mean of the eight (8) factors in determining

the competitiveness of the construction firm the overall mean of the eight (8) factors is 3.43 rated as highly agree thus confirming that all eight (8) factors are very appropriate in determining the competitiveness of the construction enterprises in Vietnam.

Comparison on the Level of Relationships between Profile of Respondents and Competition Enterprise.

As to Age (37.13), when compared to the tabular value of 26.296 which is very much higher an indication of significance relationships between age and competition enterprise.

As to gender (5.32), when compared to the tabular value of 9.488 is very much lower, thereby, indicating that there is no significant relationship between gender and competition 


\section{International Journal of Business Management and Economic Review}

Vol. 4, No. 01; 2021

ISSN: 2581-4664

enterprise as perceived by the respondents.

As to years of experience (34.32), when compared to the critical value of 26.296 is very much higher thus, indicating significant relationship of years of experience and competition enterprise as perceived by the respondent.

As to the educational attainment (27.54), is higher than the critical value of 26.296 indicating significant relationship between educational attainment and competition enterprise.

To sum it all the above statistical interpretation is indicative that there existed a significant relationship of the three profiles such as age, years of experience and educational attainment except gender registering a no significant relationship as indicative that the null hypothesis rejected in the above three profiles except gender registering no significant relationship.

\section{Factors that Reflect the Competitiveness of Construction Enterprises in Inside and Outside}

Of the seven (7) factors such as marketing equipment technology, product quality and services, strategic alliances, financial ability and corporate image indicated that the composite weighted mean of 3.76 rated as highly agree which reflect the competitiveness of construction enterprises both inside and outside.

\section{Intervention Scheme Proposed}

The interplay of the inside and outside factor marketing activity, equipment and technology, product quality, strategic alliance and corporate image as the inside factor and policies of state, client/investors, competitor and supplier as the outside factor which determine the variability and competitiveness of the construction enterprise.

\section{CONCLUSION}

Foregoing consideration of the findings with regards to the specific problems addressed in this study, the following conclusions were formulated:

1. It appears that most of the respondent falls under the age bracket of 44 years and up, male, experience ranging from 10years and below and well educate.

2. The level of competitiveness as regard to the eight (8) factors are considered as highly agree as perceived by the respondent.

3. There is significant relationship between age, year of experience and educational attainment except gender which registered no significant relationship with competition enterprises.

4. That the factor as proposed to reflect competitiveness of construction enterprises, composed of the outside factor and inside factor as reflected and is perceived by the respondent as highly agree.

\section{RECOMMENDATIONS}

Based on the findings and conclusion arrived at the following recommendation are forwarded;

1. To effectively implement the eight (8) factors that determined the competitiveness of the construction enterprises, management of the enterprise must strictly adheres on the proper approaches of living up to the expectation of customers both local and foreign. 


\section{International Journal of Business Management and Economic Review}

Vol. 4, No. 01; 2021

ISSN: 2581-4664

2. For the construction enterprises to observe transparency of the information needed by the public to guide them to transact business with the firm.

3. For the Vietnam government to review their policy related to Vietnam construction enterprises, in order to be more competitive in the world market.

For future researcher to undertake parallel study on how to enhance competitiveness of construction enterprises set in the world market.

\section{REFERENCES}

Feurer, R., \& Chaharbaghi, K. (1994). Defining competitiveness: a holistic approach. Management decision.

Hamilton, L., \& Webster, P. (2018). The international business environment. Oxford University Press.

Porter, M. E. (1980). Competitive strategy: Techniques for analyzing industries and competitors. William, T., \& James, P. D. (2006). The research methods knowledge base.

http://dpi.danang.gov.vn/chi-tiet?articleId=9081;

http://dpi.danang.gov.vn/chi-tiet?articleId=9222;

http://dpi.danang.gov.vn/detail?articleId=8988;

http://dpi.danang.gov.vn/detail?articleId=9069;

http://dpi.danang.gov.vn/detail?articleId=9174;

http://fica.vn/doanh-nghiep/kho-khan-van-tiep-tuc-bua-vay-cac-doanh-nghiep-xay-dung-

13786.html.

http://www.appc.org;

http://www.hkis.org.hk/ufiles/200712yongtan.pdf;

http://www.lib.polyu.edu;

http://www.luatvietnam.vn;

http://www.moc.gov.vn;

http://www.mt.gov.vn;

http://www.state.gov;

http://www.vneconomy.com.vn; 